\title{
Tobacco control measures under industry assault
}

$\mathrm{W}$ orld Health Organization Director Dr. Margaret Chan drew the line firmly in the sand. "I call on heads of state and heads of government to stand rockhard against the despicable efforts of the tobacco industry to subvert" the Framework Convention on Tobacco Control (FCTC), Chan told the United Nations last month. "We must stand firm against their open and extremely aggressive tactics."

Tobacco industry bids to undermine tobacco prevention and control measures by mounting legal challenges based on international trade treaties appear to have become all the rage, to the dismay of public health advocates. Australia, Norway and Uruguay now face such trade-related lawsuits. Two similar suits against Thailand and the United States were recently settled in the industry's favour. And as Chan indicated, legal skirmishing underway at the World Trade Organization suggests that many more countries will soon join the list of industry targets.

The FCTC, a 2005 initiative to which roughly 170 countries have become signatories, has been effectively used to introduce such tobacco control measures as plain packaging and expanded health warnings on cigarette packages.

But the industry is combing the fine print of trade treaties with an eye toward gutting tobacco control initiatives, says Ellen Shaffer, codirector of the San Francisco, California-based Center for Policy Analysis on Trade and Health.

The tactic was partly pioneered in Canada during mid-1990s skirmishing over the North American Free Trade Agreement, when the tobacco industry successfully repelled efforts to introduce plain packaging, Shaffer says.

A spate of recently negotiated trade agreements around the world (there are now more than 2000 such agreements), often signed without consideration of public health consequences, has fuelled

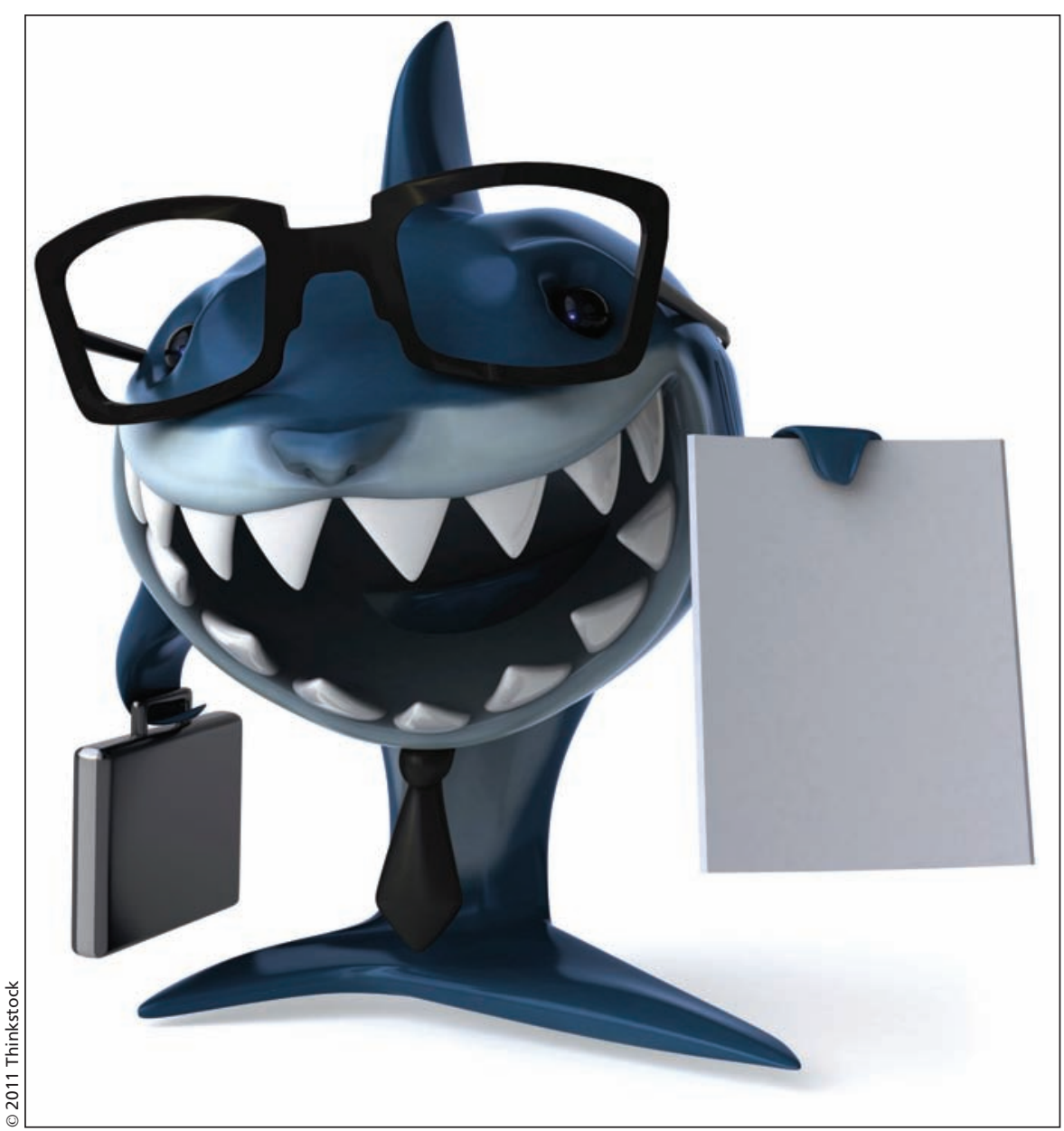

Lawyers are scouring trade agreements for grounds on which to undermine tobacco control measures.

the trend, she adds. "It's a real test of the often arcane and complex architecture of these trade agreements."

Shaffer says trade agreements have historically opened up new markets for tobacco exporters: After South Korea opened its market to US companies in 1988, for example, US cigarette exports to South Korea rose by $1000 \%$ by 1993, while smoking rates among male Korean teens rose from $18 \%$ to $30 \%$ in a single year, according to a study by the United States General Accounting Office (http://gao.justia.com/executive -office-of-the-president/1990/5/trade-and -health-issues-nsiad-90-190/NSIAD-90 -190-full-report.pdf).

"The tobacco industry is now hop- ing to seize on an interlocking web of rights gained through these trade agreements," Shaffer adds.

The legal skirmish in Australia emerged after legislators passed the world's first law requiring cigarettes to be sold in plain packages starting in 2012. The industry began scouring Australia's 26 international trade treaties and in June, a subsidiary of Phillip Morris International served a notice of claim that it would sue the Australia government for allegedly breaching a bilateral investment treaty with Hong Kong.

"The forced removal of trademarks and other valuable intellectual property is a clear violation of the terms of the 
bilateral investment treaty," the firm argued in a press release (www.pmi .com/eng/media_center/press_releases /pages/PM_Asia_plain_packaging.aspx). "We believe we have a very strong legal case and will be seeking significant financial compensation for the damage to our business."

In Uruguay, Philip Morris is challenging tobacco control measures, using a 1988 investment protection agreement with Switzerland, and in Norway, the firm is asserting that a tobacco product display ban violates the terms of the agreement that allows the Nordic nation to be a part of the European Economic Area. Indonesian trade lawyers used World Trade Organization rules to challenge US regulations banning some types of tobacco flavouring, while lawyers in the Phillippines successfully challenged tobacco control measures in Thailand on the grounds that imported cigarettes could not be taxed differently than those domestically produced.

It's a finely honed strategy on the part of the tobacco industry, and countries that are home to tobacco firms, says Cynthia Callard, executive-director of Physicians for a Smoke-Free Canada. The industry "has sharpenedup its game with respect to trade issues."

The industry and its home nations have repeatedly staved-off the inclusion of language in trade treaties that would shield tobacco control measures from legal challenges, says Francis Thompson, an analyst with the Ottawa, Ontario-based nongovernmental organization HealthBridge, and director of policy and advocacy for an international coalition that promotes the FCTC. "Many developing countries wanted language in the treaty stating that health trumps trade," Thompson says. But nations with powerful tobacco industries (such as the US, Germany, Japan and China) have "succeeded in insisting that existing trade agreements would prevail."

The American Medical Association has called for public health representa- tion on trade advisory committees to help neutralize industry influence. That would help, particularly at a time when tobacco firms have "not only coordinated their actions globally to influence national governments, but to influence, utilize or undermine international institutions," says Kelley Lee, professor and director of global health at Simon Fraser University's Faculty of Health Sciences in Burnaby, British Columbia.

Lee notes that Canada is now pushing hard for new trade deals with nations including India, where smoking rates are exploding. "The tobacco industry, via the governments of industrialized countries, can pick off one country at a time through such trade deals," she argues. "Public health advocates are only catching up with what has been going on. Representation around the table for public health advocates at bilateral trade negotiations is virtually nonexistent." - Paul Christopher Webster, Toronto, Ont.

CMAJ 2011. DOI:10.1503/cmaj.109-4020 